\title{
Discussion and exploration of management measures for slope stabilization of open pit coal mines
}

\author{
Peng Zhang ${ }^{1,2, a}$, Bo Liu ${ }^{1}$ and Yuanye Zhou ${ }^{3}$ \\ ${ }^{1}$ School of Mechanics and Civil Engineering, China University of Mining \& Technology (Beijing), \\ Beijing, 100083, China \\ ${ }^{2}$ Department of Planning and Engineering, Shenhua Baorixile Energy Co.Ltd, Hulunber, Inner \\ Mongolia, 021000, China \\ ${ }^{3}$ School of Government, Peking University, Beijing, 100871, China \\ ajans7zp@foxmail.com
}

Keywords: open pit coal mine; slope stabilization; management measures

Abstract. The efficient and high coal output of China' s opencut coal mining has made remarkable contributions to China' s modernization construction. However, it should be noted that slope instability of opencut coal mines often gives rise to a series of geological disasters. Disasters of the kind will not only do a great harm to environment, but also pose a huge threat to safe coal production. This paper explores and discusses management measures for slope stabilization of opencut coal mines. It is hoped that this research can provide some useful references for safe mining of China' $s$ coal industry.

\section{Introduction}

Coals have made great contributions to economic development and social construction. It is apt to say that coals are an indispensable basic energy to China in the current stage. Opencut coal mines have provided rich coal resources for China's development. However, mining of opencut coal mines is faced with the safety issue of slope stabilization. It is an issue of great concern. Corresponding measures should be worked out to solve problems related to slope stabilization of opencut coal mines. Only in this way can mining of opencut coal mines be safer and efficiently provide resources for relevant construction of China.

\section{Geological disasters of opencut coal mines and their characteristics}

\subsection{Characteristics of the slope of opencut coal mines}

The slope of opencut coal mines refers to the inclining surface formed by the topsoil stripping and the mine body excavation during the mining process. Therefore, opencut coal mines are characterized by timeliness, deformability, dynamic nature and non-preference of storing conditions. In terms of the slope constitution of opencut coal mines, the sedimentary rock is the key component. Since the stratification of the slope of opencut coal mines is obvious and weak structural surfaces are too many, the overall strength of the slope of opencut coal mines is relatively poor. Besides, the quaternary system topsoil is relatively thick and the soil slope of opencut coal mines is relatively high. This further influences the slope stability of opencut coal mines. Under the condition, with the deepening of mining of opencut coal mines, the height of slope keeps increasing, which might reach several thousand meters. In such high slopes, there might be several different geological conditions and slope constitutions, which pose a great threat to the safe mining of opencut coal mines [1].

1.2 Characteristics of geological disasters of opencut coal mines

Slope sliding, collapse, subsidence and debris flow are commonly-seen geological disasters of opencut coal mines. Since sedimentary rock is the major component of the slope of opencut coal mines, the slope strengthen of opencut coal mines is poor. Due to that, geological disasters frequently break out. Most of these disasters are caused by slope instability of opencut coal mines. The 
suddenness of these geological disasters has exerted a serious influence on safety of relevant personnel and normal production [2].

\section{Major factors causing geological disasters of opencut coal mines}

\subsection{Components of rock minerals}

During the geological work, it is found that different rock minerals have different physical characteristics. These physical characteristics can influence the intensity of minerals. Therefore, the commonly-seen minerals show different hardness. Some hard minerals have a strong resistance against weathering and influence; while some relatively soft or vulnerable minerals are prone to be weathered and melted. During the mining of opencut coal mines, there are many soft or vulnerable minerals are frequent to find. Due to their physical characteristics, these minerals can easily trigger some relevant geological disasters. For example, some minerals with a strong water absorbing capacity can be easily weathered, thus resulting in occurrence of sliding slope of opencut coal mines [3].

2.2 Vibration factors of blasting operation during coal mining

Blasting operation is an important mining method for opencut coal mines. During the blasting operation process, the vibration thus caused might exert an extremely serious influence on stability of opencut coal mines. Blasting operation influences slope stability of opencut coal mines from three aspects:

2.2.1 Blasting operation of opencut coal mines destroys the slope rock mass, thus increasing vulnerability of rocks with a low intensity and resulting in internal looseness of rocks. After loosening of rocks, the corrosion of rainwater and underground water will seriously corrode rocks within the slope of opencut coal mines, accelerating their weathering and finally reducing the slope stability of opencut coal mines.

2.2.2 The vibration caused by blasting operation of opencut coal mines results in sliding of rocks of the slope of opencut coal mines and decreased stability of the slope of opencut coal mines.

2.2.3 The vibration caused by blasting operation of opencut coal mines might destroy the rock structure within the slope of opencut coal mines, thus greatly impairing its damage-resistance and directly influencing slope stability of opencut coal mines [4].

\section{Management measures for slope stability of opencut coal mines}

Slope stability of opencut coal mines plays an important role in maintaining normal coal production. Especially during the rainy season of some places, the large amount of precipitation increases the water content of opencut coal mines and the occurrence rate of sliding slope of opencut coal mines. In order to enhance slope stability of China's opencut coal mines and guarantee the normal and safe development of industries related to coal mining, this paper puts forward the following measures based on working experiences of the author:

3.1 Sewer drainage

Concerning decreasing slope stability of opencut coal mines caused by precipitation, relevant opencut coal mine enterprises should build all kinds of drainage and interception facilities, such as intercepting ditches, drainage ditches and torrent tanks. Through these facilities, the influence of surface water on slope stability of opencut coal mines can be efficiently prevented and controlled. In terms of underground water of the slope of opencut coal mines, relevant enterprises can build facilities like water-collecting wells, seepage wells and sand wells to prevent underground water from falling into the slope of opencut coal mines and increase slope stability of opencut coal mines [5].

3.2 Establishment of specialized slope monitoring stations for opencut coal mines

In order to efficiently reduce the occurrence probability of geological disasters of opencut coal mines, relevant enterprises should set up professional and comprehensive slope monitoring stations near the opencut coal mines, and form a monitoring network system of opencut coal mines. The slope 
monitoring stations should not only monitor the slope surface of opencut coal mines, but also conduct a 3D monitoring of opencut coal mines. During the construction process of the monitoring network system, relevant enterprises should draft a thorough plan to facilitate the construction work. Besides, these enterprises should build monitoring stations on the major sliding surface of opencut coal mines, the sliding surface with certain occurrence probability of geological disasters and the geological delamination on the slope. Meanwhile, focus should be on monitoring sections where geological disasters are prone to happen and where weathering is relatively serious. In this way, geological disasters related to the slope of opencut coal mines can be discovered and prevented at an earlier date, and the occurrence probability of geological disasters during the daily mining process of opencut coal mines can be maximally reduced [6].

3.3 Coordination between mining of opencut coal mines and slope management

During the mining process, slope maintenance can guarantee normal and safe production of opencut coal mines. During the slope maintenance process, relevant maintenance personnel should fully coordinate with mining personnel so as to minimize the exposure duration and service years of the slope of opencut coal mines. By doing so, they can jointly reduce the occurrence probability of geological disasters in the slope. To achieve full coordination between maintenance and mining personnel, mining personnel should choose proper mining techniques, mining area allocation and operating line promotion. Besides, mining personnel can minimize the sliding of the slope of opencut coal mines through the internal dumping and slope toe pressing project to guarantee smooth mining progress of opencut coal mines.

\section{Conclusions}

According to the exploration of management measures for slope stabilization of opencut coal mines in this paper, the author learns characteristics of geological disasters of opencut coal mines, major factors resulting in occurrence of these geological disasters and management measures for slope stabilization of opencut coal mines. Concerning the commonly-seen geological disasters in the slope of opencut coal mines, relevant enterprises should conduct maintenance of the slope, such as building a professional and comprehensive slope monitoring network system, promoting communication between coal mining personnel and maintenance personnel, and guaranteeing the safe and orderly progress of coal mine production.

\section{References}

[1]Zhang J H, Tian L M and Ren H B. Management measures for slope stabilization of opencut coal mines[J]. Journal of Langfang Teachers University (Natural Science Edition), 2015,04:90-91+94.

[2]Guo R \& Li Q Q. Analysis of factors influencing slope stabilization of South Opencut Coal Mine of Dajing Mine Area [J]. Inner Mongolia Science Technology \& Economy,2015,17:64-65.

[3]Wang SH K, Yu Q B, Tian Y, et al. Application of TM30 deformation monitoring system to early warning of slope sliding of opencut coal mines[J].Coal Science \& Technology Magazine,2013,03:61-63.

[4]Ji Y SH, Sun H R \& Liu J H. Geological hazards analysis and control for slope sliding and surface deformation before and after mining in deep open-pit coal mine[J]. Chinese Journal of Rock Mechanics and Engineering,2006,S1:2848-2853.

[5]Fan J F, Song Z L \& Wang D. Analysis research of influence of groundwater on slope stability in Lingquan open-pit mine[J]. Journal of Water Resources \& Water Engineering,2011,05:121-125.

[6]Cui T J, Ma Y D \& Wang L G. Study on slope stabilization of opencut coal mines Based on PEC3D residue coal spontaneous combustion[J]. Journal of Natural Disasters,2016,01:169-175. 